\title{
Nutrient Releasing Pattern of Humic Acid Coated Phosphatic Fertilizers
}

\author{
R.K. Kaleeswari \\ Department of Soil Science and Agricultural Chemistry, Tamil Nadu Agricultural University, Coimbatore, India \\ Corresponding author: kaleeswarisenthur@gmail.com
}

Received: 24-03-2021

Revised: $12-05-2021$

Accepted: $10-06-2021$

\begin{abstract}
An experiment was conducted to standardize the humic acid coating for Mono ammonium Phosphate (MAP) and Single Super Phosphate (SSP). The levels of humic acid coating were 5, 10, 15 and 20 per cent. The design of the experiment was completely randomized design replicated thrice. The nutrient $P$ release from the humic acid coated fertilizers was recorded at 6 hours intervals up to 72 hours. The Fourier transmission infrared spectroscopy characterization of MAP coated with 5\% HA and MAP coated with $10 \%$ HA revealed the presence of functional groups such as alkenes, alcohols, aromatics, amine salts (primary and secondary) as well as halogens (free and coupled). The results revealed that a higher rate of $\mathrm{P}$ release was observed due to the application of MAP coated with 5 per cent and 10 per cent humic acid had a greater rate of $P$ release whereas higher levels of humic acid coatings (15 per cent and 20 per cent) recorded a lesser rate of P release.
\end{abstract}

Keywords: Coated fertilizers, Humic acid, Phosphorus, Release pattern

A major hindrance to crop production Worldwide is low phosphorus availability. Assessment of overall efficiency of applied fertilizer is reported to be about or lesser than $50 \%$ for $\mathrm{N}$, about $40 \%$ for $\mathrm{K}$ and less than $20 \%$ for P. Considering the low recovery of applied and native $\mathrm{P}$ and the high cost of chemical phosphatic fertilizers in addition to an increasing concern about environmental degradation it is important to find viable sources of $\mathrm{P}$ to increase fertilizer use efficiency (Sarkar et al. 2017). The use of humic acids in crop production emerges as key sustainable technologies are involved in uptake of nutrients and can increase root and shoot growth. The use of biodegradable chitosan to coat fertilizer granules with an inert, impermeable layer facilitated controlled release properties (Lubkowski, 2014). Coating with humic acids reduced the water solubility of the P fertilizers increased the agronomic efficiency of $\mathrm{P}$ led to higher values of apparent $P$ recovery by maize (Teixeira et al. 2016).
Significant role of humic acid in the release of $\mathrm{P}$ was reported by Jamal et al. (2018). Humic acid at low concentration can act as an activator of nutrient uptake and plant growth ( Tehranifar and Ameri, 2012). The solubilization of single super phosphate can be increased byorbital milling process which accelerates it by reducing the effective particle size of this fertilizer. (Plotegher and Ribeiro, 2016). Combining or coating of $\mathrm{P}$ fertilizers with humic acid can be an effective way to improve the $\mathrm{P}$ status of the soil. An experiment was conducted to standardize the humic acid coating for Mono ammonium Phosphate (MAP) and Single Super Phosphate (SSP).

How to cite this article: Kaleeswari, R.K. (2021). Nutrient Releasing Pattern of Humic Acid Coated Phosphatic Fertilizers. International Journal of Bioresource Science, 08(01): 15-19.

Source of Support: None; Conflict of Interest: None 


\section{MATERIALS AND METHODS}

\section{Preparation of coated fertilizers}

For the preparation of humic acid (HA) coated Mono ammonium Phosphate (MAP) and Single Super Phosphate (SSP), calculated quantity of humic acid required for coating at different percentages (If $100 \mathrm{~g}$ MAP/SSP was taken 5,10,15 and $20 \mathrm{~g}$ of humic acid is required for coating at 5,10,15 and $20 \%$ respectively) were added with MAP and SSP. The fertilizer humic acid mixture and starch were mixed and dried. Limited amount of starch was added in to the fertilizer mixture. The dried material was ground and used for the study.

\section{Characterisation of HA coated phosphatic fertilizers (FTIR spectroscopy)}

The characterization of HA coated phosphatic fertilizers was done using FTIR (Fourier transmission infrared spectroscopy) and the functional groups present were identified.

\section{Column study}

A column study was conducted to study the P release pattern from the humic acid coated MAP and SSP. Humic acid coated MAP and SSP at various levels (5\%,10\%,15\% and 20\%) were applied in the column filled with soil. P concentration in the leachate was determined. (Braga and Defelipo, 1974) using ascorbic acid method. The design of the experiment was completely randomized design replicated thrice. The soil leaching columns were prepared using PVC pipes of length15 cm and diameter $20 \mathrm{~cm}$. Soil samples were taken, air dried, clods were removed and filled in columns up to $7.5 \mathrm{~cm}$ height. A total of 24 columns were prepared with 8 treatments: T1: HA coated MAP (5\%); T2: HA coated MAP (10\%); T3: HA coated MAP (15\%); T4: HA coated MAP (20\%); T5: HA coated SSP (5\%); T6: HA coated SSP $(10 \%)$; T7: HA coated SSP (15\%) and T8: HA coated SSP (20\%). $5 \mathrm{~g}$ of each fertilizer was added in each column. Water was applied at 4 hours interval and leachate samples were collected. P concentration in leachate samples were analysed using ascorbic acid method. To $50 \mathrm{ml}$ of leachate sample and or standards, add $1 \mathrm{ml}$ of $11 \mathrm{~N}$ sulphuric acid and $4 \mathrm{ml}$ of ammonium molybdate-antimany potassium tartarate were added and mixed. Ascorbic acid solution $(2 \mathrm{ml})$ was added and mixed. After 5 minutes, the absorbance at $660 \mathrm{~nm}$ was measured using spectrophotometer and the P concentration was determined.

\section{RESULTS AND DISCUSSION}

The column study was conducted using composite surface soil sample $(0-15 \mathrm{~cm})$ belongs to Irugur soil series (Typic Ustropept). The soil texture was loamy sand with a bulk density of $1.26 \mathrm{Mg} \mathrm{m}^{-3}$. Soil reaction, electrical conductivity and cation exchange capacity of the soil were $7.83,0.60 \mathrm{dSm}^{-1}$ and 23.40 $\mathrm{C}$ mol $\left(\mathrm{p}^{+}\right) \mathrm{kg}^{-1}$ respectively. Alkaline $\mathrm{KMnO}_{4}-\mathrm{N}(238$ $\left.\mathrm{kg} \mathrm{ha}^{-1}\right)$, Olsen-P $\left(64 \mathrm{~kg} \mathrm{ha}^{-1}\right), \mathrm{NH}_{4} \mathrm{OAc}-\mathrm{K}(170 \mathrm{~kg}$ $\left.\mathrm{ha}^{-1}\right)$, organic carbon $\left(5.20 \mathrm{~g} \mathrm{~kg}^{-1}\right)$, DTPA-Zn $(5.37 \mathrm{mg}$ $\left.\mathrm{kg}^{-1}\right)$, DTPA-Fe (4.49 $\left.\mathrm{mg} \mathrm{kg}^{-1}\right)$, DTPA-Mn (6.80 mg $\left.\mathrm{kg}^{-1}\right)$ and DTPA-Cu $\left(4.90 \mathrm{mg} \mathrm{kg}^{-1}\right)$ were the fertility status of the soil.

\section{Characterization of HA coated phosphatic fertilizers}

The FTIR (Fourier transmission infrared spectroscopy) characterization of MAP coated with 5\% HA (Table 1) and MAP coated with 10\% HA (Table 2) revealed the presence of functional groups such as alkenes, alcohols, aromatics, amine salts (primary and secondary) as well as halogens (free and coupled).

Chen et al. (2002) studied about the characterization of soil organic matter using FTIR and reported abundant amount of methoxyl $\left(-\mathrm{OCH}_{3}\right)$ and aromatic $(\mathrm{C} \equiv \mathrm{C})$ functional groups in SHA (soil humic acid). Pérez et al. (2004) revealed the presence of functional groups such as are -OH groups, - $\mathrm{COOH}$ groups, ketones, aromatic groups, and aliphatic compounds in the humic acid fraction of Oxisols. Tatzber et al. (2007) reported the abundance of alcohols, aromatics, aliphatic groups as well as carboxyl groups (aldehydes and ketones) when humic acids and humin fractions were characterized using FTIR spectroscopy.

\section{Total P content in soil leachate samples}

Total P content in the leachate was analysed at various time intervals viz., 6, 12, 18 and 24 hours after the application of fertilizers viz., MAP and SSP coated with humic acid as per the treatment schedule. At 12 hours interval the average $P$ release from $10 \%$ HA coated MAP was $0.84 \mathrm{mg} \mathrm{l}^{1^{-1}}$ 
Table 1: Characterization of HA coated Phosphatic fertilizer using FTIR Spectroscopy (MAP coated with 5 \% HA)

\begin{tabular}{llll}
\hline Sl. No. & Classification & Groups & Remarks \\
\hline 1 & Alcohols & $\mathrm{Ph}-\mathrm{CHR}-\mathrm{OH}$ & Hydrogen bonded, broad peak \\
2 & Alkenes & $\mathrm{Ph}-\mathrm{CH}=\mathrm{CH}-\mathrm{R}$ & Phenyl conjugated $\mathrm{C}=\mathrm{C}$ \\
3 & Alkenes & $\mathrm{C}=\mathrm{C}$ cyclic & Two peaks, two or more $\mathrm{C}=\mathrm{C}$ groups shows additive nature \\
4 & Alkenes & $\mathrm{CCH}=\mathrm{CHCC}$ & Non-conjugated $\mathrm{C}=\mathrm{C}$ \\
5 & Silicon compounds & $\mathrm{SiCl}_{2}$ & \\
6 & Alcohols & $\mathrm{R}-\mathrm{CH}_{2} \mathrm{OH}$ & Hydrogen bonded, broad peak \\
7 & Alkynes & $\mathrm{R}-\mathrm{C} \equiv \mathrm{C}-\mathrm{R}$ & di-substituted \\
8 & Aromatics & $1,2,3,4$ substituted & \\
9 & Amine salts & $\mathrm{NH}_{2}{ }^{+}$ & Secondary amine salt, broad peak, often multiple bands \\
10 & Silicon compounds & $\mathrm{R}_{3} \mathrm{Si}_{-} \mathrm{OH}$ & Broad peak \\
11 & Sulphur compunds & $\mathrm{R}-\mathrm{SOOH}^{-}$ & Broad peak \\
12 & Amine salts & $\mathrm{NH}_{3}{ }^{+}$ & Primary amine salt, broad peak,often multiple bands \\
13 & Ethers & $\mathrm{R}-\mathrm{CH} \mathrm{H}_{2}-\mathrm{CH}{ }_{2}-\mathrm{R}$ & Anti symmetric stretching \\
14 & Halogens & $\mathrm{C}-\mathrm{Br}$ & \\
15 & Halogens & $\mathrm{C}-\mathrm{I}$ & \\
\hline
\end{tabular}

Table 2: Characterization of HA coated Phosphatic fertilizer using FTIR Spectroscopy (MAP coated with $10 \% \mathrm{HA}$ )

\begin{tabular}{llll}
\hline Sl. No. & Classification & Groups & Remarks \\
\hline 1 & Alcohols & $\mathrm{R}-\mathrm{CH}_{2}-\mathrm{OH}$ & Hydrogen bonded, broad peak \\
2 & Alkenes & $\mathrm{Ph}-\mathrm{CH}=\mathrm{CH}-\mathrm{R}$ & Phenyl conjugated $\mathrm{C}=\mathrm{C}$ \\
3 & Alkynes & $\mathrm{R}-\mathrm{C} \equiv \mathrm{C}-\mathrm{R}$ & di-substituted \\
4 & Aromatics & $1,2,3,4$ substituted & 2 Adjacent $\mathrm{H}$ out of plane deformation \\
5 & Aromatics & $1,2,3,5$ substituted & 1 Adjacent $\mathrm{H}$ out of plane deformation \\
6 & Aromatics & $1,2,3,4,5$ substituted & 1 Adjacent $\mathrm{H}$ out of plane deformation \\
7 & Silicon compounds & $\mathrm{R}_{3} \mathrm{Si}-\mathrm{OH}$ & Broad peak \\
8 & Alcohols & $\mathrm{Ph}-\mathrm{CHR}-\mathrm{OH}$ & Hydrogen bonded, broad peak \\
9 & Sulphur compunds & $\mathrm{R}-\mathrm{SOOH}$ & Broad peak \\
10 & Amine salts & $\mathrm{NH}_{3}{ }^{+}$ & Primary amine salt, broad peak,often multiple bands \\
11 & Ethers & $\mathrm{R}-\mathrm{CH}_{2}-\mathrm{CH}{ }_{2}-\mathrm{R}$ & \\
12 & Halogens & $\mathrm{C}-\mathrm{Br}$ & \\
13 & Halogens & $\mathrm{C}-\mathrm{I}$ & \\
14 & Phosphorus & $\mathrm{Co} \mathrm{P-F}$ & \\
15 & Phosphorus & $\mathrm{Co} \mathrm{P-Cl}$ & \\
\hline
\end{tabular}

while P release from $10 \%$ HA coated SSP was 0.36 $\mathrm{mg}^{-1}$ (Table 3).

During the next stage, viz 30, 36, 42 and hours after the application of fertilizers, the highest average $\mathrm{P}$ release was recorded at 42 hours with the application of MAP coated with 10\% HA $(0.48$ $\left.\mathrm{mg}^{-1}\right)$. However, SSP coated with 5\% HA recorded a $\mathrm{P}$ release of $0.20 \mathrm{mg} \mathrm{l}^{-1}$. The highest $\mathrm{P}$ release was recorded by the application of MAP coated with $5 \%$ HA and $10 \%$ HA whereas HA coated SSP registered lower P release (Table 4).

After 66 hours of application of fertilizers the highest average $P$ release was observed with the application of MAP coated with 5\% HA (0.83 mg
$\mathrm{I}^{-1}$ ) while the lowest $\mathrm{P}$ release was with SSP coated with $10 \%$ HA $\left(0.16 \mathrm{mg} \mathrm{l}^{-1}\right)$ (Table 5).

The application of MAP coated with 5\% HA and $10 \%$ HA registered the highest $\mathrm{P}$ content while HA (10\%, 15\% and 20\%) coated SSP recorded the lowest total P content. This could be ascribed to the higher content of P in MAP (62\%) whereas in SSP, P content was lesser (16\%).

This corroborate with the findings of Teixeira et al. (2016) who conducted a water solubility test with the coated MAP andfound that the P release from fertilizer could be related to the hydrophilicity or hydrophobicity of the coating material.

A similar trend of the molecular characteristics of 
Table 3: Total $\mathrm{P}$ content $\left(\mathrm{mg} \mathrm{l}^{-1}\right)$ in soil leachate samples at 6, 12, 18 and 24 hours after P added: Column study (Mean value of three replications)

\begin{tabular}{lllll}
\hline \multirow{2}{*}{ Treatments } & \multicolumn{3}{c}{ Duration (Hours) after P added } \\
\cline { 2 - 5 } & $\mathbf{6}$ & $\mathbf{1 2}$ & $\mathbf{1 8}$ & $\mathbf{2 4}$ \\
\hline T1: HA coated MAP (5\%) & 0.62 & 0.77 & 0.56 & 0.33 \\
T2: HA coated MAP (10\%) & 0.53 & 0.84 & 0.54 & 0.45 \\
T3: HA coated MAP (15\%) & 0.24 & 0.49 & 0.31 & 0.21 \\
T4: HA coated MAP (20\%) & 0.36 & 0.44 & 0.21 & 0.12 \\
T5: HA coated SSP (5\%) & 0.24 & 0.35 & 0.15 & 0.08 \\
T6: HA coated SSP (10\%) & 0.14 & 0.36 & 0.21 & 0.05 \\
T7: HA coated SSP (15\%) & 0.11 & 0.24 & 0.14 & 0.11 \\
T8: HA coated SSP $(20 \%)$ & 0.13 & 0.31 & 0.16 & 0.08 \\
\hline Mean & 0.30 & 0.46 & 0.26 & 0.18 \\
\hline CD (P:0.05) & 0.08 & 0.12 & 0.73 & 0.05 \\
\hline
\end{tabular}

Table 4: Total P content $\left(\mathrm{mg} \mathrm{l}^{-1}\right)$ in soil leachate samples at 30, 36, 42 and 48 hours after P added: Column study (Mean value of three replications)

\begin{tabular}{lllll}
\hline \multirow{2}{*}{ Treatments } & \multicolumn{3}{c}{ Duration (Hours) after P added } \\
\cline { 2 - 5 } & $\mathbf{3 0}$ & $\mathbf{3 6}$ & $\mathbf{4 2}$ & $\mathbf{4 8}$ \\
\hline T1: HA coated MAP (5\%) & 0.31 & 0.37 & 0.48 & 0.53 \\
T2: HA coated MAP (10\%) & 0.22 & 0.41 & 0.52 & 0.51 \\
T3: HA coated MAP (15\%) & 0.25 & 0.17 & 0.37 & 0.29 \\
T4: HA coated MAP (20\%) & 0.13 & 0.13 & 0.20 & 0.34 \\
T5: HA coated SSP (5\%) & 0.08 & 0.07 & 0.15 & 0.24 \\
T6: HA coated SSP (10\%) & 0.05 & 0.06 & 0.20 & 0.13 \\
T7: HA coated SSP (15\%) & 0.10 & 0.10 & 0.13 & 0.10 \\
T8: HA coated SSP (20\%) & 0.08 & 0.05 & 0.17 & 0.14 \\
\hline Mean & 0.15 & 0.17 & 0.28 & 0.28 \\
\hline CD (P:0.05) & 0.05 & 0.05 & 0.08 & 0.07 \\
\hline
\end{tabular}

Table 5: Total P content $\left(\mathrm{mg} \mathrm{l}^{-1}\right)$ in soil leachate samples at 54, 60, 66 and 72 hours after P added: Column study (Mean value of three replications)

\begin{tabular}{lllll}
\hline \multirow{2}{*}{ Treatments } & \multicolumn{3}{c}{ Duration (Hours) after P added } \\
\cline { 2 - 5 } & $\mathbf{5 4}$ & $\mathbf{6 0}$ & $\mathbf{6 6}$ & $\mathbf{7 2}$ \\
\hline T1: HA coated MAP (5\%) & 0.78 & 0.54 & 0.83 & 0.46 \\
T2: HA coated MAP (10\%) & 0.94 & 0.52 & 0.75 & 0.36 \\
T3: HA coated MAP (15\%) & 0.47 & 0.38 & 0.44 & 0.43 \\
T4: HA coated MAP (20\%) & 0.43 & 0.35 & 0.42 & 0.31 \\
T5: HA coated SSP (5\%) & 0.39 & 0.29 & 0.31 & 0.28 \\
T6: HA coated SSP (10\%) & 0.41 & 0.24 & 0.16 & 0.21 \\
T7: HA coated SSP (15\%) & 0.29 & 0.18 & 0.21 & 0.13 \\
T8: HA coated SSP (20\%) & 0.36 & 0.12 & 0.22 & 0.17 \\
\hline Mean & 0.51 & 0.33 & 0.42 & 0.29 \\
\hline CD $($ P:0.05) & 0.13 & 0.08 & 0.12 & 0.08 \\
\hline
\end{tabular}

the HA with an intermediate hydrophobicity would have favoured maximum release of $\mathrm{P}$ over time. Increased P availability was reported from polymer coated MAP fertilizer granule by Pauly et al. (2002); Wu et al. (2008); Tyliszczak et al. (2009); Jia et al. (2013) and Ahmad et al. (2015).

This column study revealed that the solubility and mobility of $\mathrm{P}$ from HA coated MAP was higher than HA coated SSP fertilizers.

\section{CONCLUSION}

A higher rate of $\mathrm{P}$ release was observed due to the application of MAP coated with 5\% HA and $10 \%$ HA. The results from the study indicate that lower 
levels HA coatings ( $5 \%$ and $10 \%$ ) on MAP had a greater rate of $\mathrm{P}$ release whereas with higher levels of HA coatings (15\% and $20 \%$ ) recorded a lesser rate of $\mathrm{P}$ release. HA coated SSP at all levels recorded a lower P release.

\section{REFERENCES}

1. Sarkar, A., Biswas, D., Datta, S., Manjaiah, K. and Roy, T. 2017. "Release of phosphorus from laboratory made coated phosphatic fertilizers in soil under different temperature and moisture regimes." Proceedings of the National Academy of Sciences, India Section B: Biological Sciences, 87(4): 1299-1308.

2. Ahmad, N., Fernando, W. and Uzir, M. 2015. “Parametric evaluation using mechanistic model for release rate of phosphate ions from chitosan-coated phosphorus fertiliser pellets." Biosystems Engineering, 129: 78-86.

3. Braga, J. and Defelipo, B. 1974. "Spectrophotometric determination of phosphorus in soil and plant extracts." Rev. Ceres, 21: 73-85.

4. Chen, J., Gu, B., LeBoeuf, E.J., Pan, H. and Dai, S. 2002. "Spectroscopic characterization of the structural and functional properties of natural organic matter fractions." Chemosphere, 48(1): 59-68.

5. Jia, X., Ma, Z.-y., Zhang, G.-x., Hu, J.-m., Liu, Z.-y., Wang, H.-y. and Zhou, F. 2013. "Polydopamine film coated controlled-release multielement compound fertilizer based on mussel-inspired chemistry." Journal of Agricultural and Food Chemistry, 61(12): 2919-2924.

6. Lubkowski, K. 2014. “Coating fertilizer granules with biodegradable materials for controlled fertilizer release." Environmental Engineering \& Management Journal (EEMJ), 13(10).

7. Pauly, D., Malhi, S. and Nyborg, M. 2002. “Controlledrelease $\mathrm{P}$ fertilizer concept evaluation using growth and $\mathrm{P}$ uptake of barley from three soils in greenhouse." Canadian Journal of Soil Science, 82(2): 201-210.
8. Pérez, M.G., Martin-Neto, L., Saab, S.C., Novotny, E.H., Milori, D.M., Bagnato, V.S., Colnago, L.A., Melo, W.J. and Knicker, H. 2004. "Characterization of humic acids from a Brazilian Oxisol under different tillage systems by EPR, 13C NMR, FTIR and fluorescence spectroscopy." Geoderma, 118(3-4): 181190.

9. Plotegher, F. and Ribeiro, C. 2016. "Characterization of Single Superphosphate Powders-a study of Milling Effects on Solubilization Kinetics." Materials Research, 19(1): 98-105.

10. Tatzber, M., Stemmer, M., Spiegel, H., Katzlberger, C., Haberhauer, G., Mentler, A. and Gerzabek, M.H. 2007. "FTIR-spectroscopic characterization of humic acids and humin fractions obtained by advanced $\mathrm{NaOH}, \mathrm{Na}_{4} \mathrm{P}_{2} \mathrm{O}_{7^{\prime}}$ and $\mathrm{Na}_{2} \mathrm{CO}_{3}$ extraction procedures." Journal of Plant Nutrition and Soil Science, 170(4): 522-529.

11. Tehranifar, A. and Ameri, A. 2012. “Effect of Humic acid on Nutrient uptake and Physiological characteristics of Fragaria × Ananassa 'camarosa'." VII International Strawberry Symposium 1049.

12. Teixeira, R.D.S., Ribeiro da Silva, I., Nogueira de Sousa, R., Márcio Mattiello, E. and Barros Soares, E.M. 2016. "Organic acid coated-slow-release phosphorus fertilizers improve $\mathrm{P}$ availability and maize growth in a tropical soil." Journal of Soil Science and Plant Nutrition, 16(4): 1097-1112.

13. Tyliszczak, B., Polaczek, J., Pielichowski, J. and Pielichowski, K. 2009. "Preparation and Properties of Biodegradable Slow-Release PAA Superabsorbent Matrixes for Phosphorus Fertilizers." Macromolecular symposia.

14. Wu, L., Liu, M. and Liang, R. 2008. “Preparation and properties of a double-coated slow-release NPK compound fertilizer with superabsorbent and waterretention." Bioresource Technology, 99(3): 547-554. 
